Original Article:

\title{
Awareness and use of PPE among radiographic workers working in some selected Government and Private Hospital in Dhaka City. Farhana Salim ${ }^{1}$, Iffat Nowshin', Meherunnessa Begum ${ }^{3}$
}

\begin{abstract}
:
Aim: This was a descriptive cross sectional study with an aim to find out the occurrences of awareness and use of PPE among the radiographic workers. Methods: The study was conducted among 80 radiographic workers working in 30 different X-ray installations in Dhaka city. Data were collected by direct interviewing of the respondents by using structured questionnaires. Result: Out of all respondents, 93.8\%were male and 6.2\% were female. Fifty two percent were within the age group 31-40 years. Forty-five percent of all the respondents had higher academic qualification on radiography and eighty-six percent of them were trained in radiography. Ninetynine percent of the workers were aware about using personal protective equipments and Ninetyseven percent were aware about using monitoring devices. However PPE was used by ninety-two percent and radiation monitoring devices by only thirty-six percent. Conclusion: Appropriate protective devices and monitoring devices were not available in most the installations.
\end{abstract}

Keywords: Radiographic workers; Personal Protective Equipments (PPE); X-Ray installation; Occupational safety.

Bangladesh Journal of Medical Science Vol. 21 No. 01 January'22 Page : 114-119 DOI: https://doi.org/10.3329/bjms.v21i1.56336

\section{Introduction:}

Radiation is present in nature and can be produced artificially. Natural or background radiation is present everywhere and each and every individual is exposed to it. Artificial or manmade radiation is in use for more than 100 years and persons exposed to it are the workers, patients in clinical set-up and the victims of nuclear disasters. The biological effects of ionizing radiations depends on the magnitude of dose and also on a number of other factors, namely whether the radiation is to the whole body or only to parts of the body, its energy and hence whether the radiation is penetrating or superficial, and finally whether it is radiation from an external source or from radioactive materials deposited in tissues-internal radiation. These effects will also depend on whether the radiation is received acutely or is accumulated over a period of time, i.e. dose rate ${ }^{1}$. Due to wide indiscriminate use, $\mathrm{x}$-ray radiation may cause different serious health hazards like carcinogenicity, mutagenceity and teratogenceity. Occupational exposures can produce a wide range of adverse effects on reproduction. The effects of parental exposure before conception may be evident as reduced fertility, unsuccessful fertilization or implantation or an abnormal fetus. Maternal exposure after conception may result in death of the fetus or structural and functional abnormalities of the newborn. Other possible adverse outcomes include spontaneous abortion (both early and late), major or minor birth defects, perinatal death, low birth weight, developmental or behavioral disabilities and transplacental exposure of carcinogens ${ }^{2,3}$. Hereditary or genetic effects of radiation may be chromosome mutation or gene mutation. Chromosome mutation

1. Dr. Farhana Salim, Associate Professor, Community Medicine Department, Shaheed Monsur Ali Medical College. E-mail: farhanasalim@yahoo.com

2. Dr. Iffat Nowshin, Associate Professor, Community Medicine Department, Shaheed Monsur Ali Medical College.

3. Dr. Meherunnessa Begum, Associate Professor, Community Medicine Department, Ibn Sina Medical College .

Correspondence: Dr. Farhana Salim, Associate Professor, Community Medicine Department, Shaheed Monsur Ali Medical College. E-mail: farhanasalim@yahoo.com 
causes sterility whereas point mutation affects gene $\mathrm{e}^{4}$. Exposure to heavy doses of radiation during the period of organogenesis leads to malformations such as microcephaly, blindness, skull defects, and spina bifida. Children born to women who received x-ray treatment during pregnancy are more likely to develop birth defects, developmental anomalies or cancer ${ }^{5}$. $\mathrm{X}$-ray used for diagnostic procedures is one of the major sources of radiation to general population. In developing countries like Bangladesh the main sources of the radiation exposure to workers occur from diagnostic $\mathrm{x}$-ray machines in health care settings i.e occupational exposure. Occupational health and safety is about ensuring a safe workplace. It is essential for all employers to provide a safe working environment for all employees. Employees have the right to know what hazardous materials, equipment or processes they work with or could be exposed to, and what they can do to avoid injury or illness when working with these materials, equipment or process. Most of the workers working in the x-ray facilities in our country have insufficient knowledge about using personal protective and radiation monitoring devices to make themselves safe from radiation hazards. Although Bangladesh Government has set the rules (Nuclear safety and radiation control act-1993; Nuclear safety and radiation control rules-1997) for regular radiation monitoring for the radiographic workers to identify the maximum permissible limit for an individual, only few follow them because of lack of knowledge and negligence. Although radiation may cause different health hazards, the aim of this study was to identify the levels of awareness and use of protective equipment in radiographic workers who are working in prolong exposure to moderate to low doses of ionizing radiation in our country context.

\section{Materials and methods:}

Type of study: It was a cross sectional descriptive study.

Study place or area: Data had been collected from 30 selected Government and private hospitals and diagnostic centers in Dhaka City where X-ray facilities are available. Study areas were selected purposively and large Government Hospitals and Private diagnostic centers were included where maximum numbers of radiographic workers were available.

Study population: Radiographic workers from different hospitals and diagnostic facilities had been taken as study population. These included both male and female Medical technologists in radiology section, nurses and technicians handling the fluoroscopy in cath lab of angiogram section and dark room assistants of different hospitals.

Inclusion criteria of the respondents were: 1.Age group: 25-50 years, 2.Married for at least 3 years, 3.Working as a medical technologist in radiology section for at least 5 years, 4 . With or without children.

Sample size and Sampling technique: A total of 80 radiographic workers from 30 hospitals and diagnostic centers were selected purposively. All the radiographic workers working in 30 hospital and diagnostic centers were interviewed. Then according to the inclusion criteria 80 samples were determined.

Data collection instrument: A structured pretested questionnaire was used in this study as research instrument.

Data collection procedure: Data were collected by direct interviewing of the radiographic workers according to the prepared structured questionnaire.

Data processing and analysis: The data were analyzed by preparing master sheet with the help of computer. Appropriate tables were prepared according to the findings, which were relevant to the study objectives. Finally data interpretation was done.

\section{Results:}

Data were collected from 80 Radiographic workers, who are working in different hospitals and diagnostic centers in Dhaka city. Out of the respondents $75(93.8 \%)$ were male whereas only $5(6.2 \%)$ respondents were female. Most of the respondents were within the range of $31-40$ years $(52.5 \%)$. Majority i.e.77 (96.2\%) of the respondents was Muslim whereas only 3(3.8\%) respondents were Hindu. Among all respondents 16(20\%) were SSC passed, 16(20\%) were HSC passed, 36(45\%) were Diploma holder, $8(10 \%)$ were Graduate and $4(5 \%)$ were Masters Degree holder.

Table 1: Distribution of Respondents by length of service (year) as Radiographic worker

\begin{tabular}{|c|c|c|}
\hline Length of service (year) & Respondents & Percentage (\%) \\
\hline 5 & 7 & 8.8 \\
\hline $6-10$ & 17 & 21.3 \\
\hline $11-20$ & 38 & 47.5 \\
\hline $20>$ & 18 & 22.5 \\
\hline Total & 80 & 100.0 \\
\hline
\end{tabular}


Mean: 15.38years, Standard deviation: \pm 7.15 years. This table shows that $38(47.5 \%)$ workers worked as radiographic worker for 11-20 years, while7 (8.8\%) worked for 5 years, $17(21.3 \%)$ worked for 6-10 years and $18(22.5 \%)$ worked for more than 20 years. The mean length of service of all workers is 15.38 years with standard deviation of \pm 7.15 years.

Table 2: Distribution of Respondents by daily average working hour

\begin{tabular}{|c|c|c|}
\hline Daily working hour & Number & $\mathbf{\%}$ \\
\hline $1-6$ & 21 & 26.3 \\
\hline $7-8$ & 40 & 50.0 \\
\hline$>8$ & 19 & 23.8 \\
\hline Total & 80 & 100.0 \\
\hline
\end{tabular}

Mean: 8.17hours, Standard deviation: \pm 2.3 hours.

This table shows that most of the workers $(40 ; 50 \%)$ work for 7-8 hours a day on average.21 (26.3\%) workers work for 1-6 hours and $19(23.8 \%)$ work for more than 8 hours.

Table 3: Distribution of Respondents by having Training on radiography

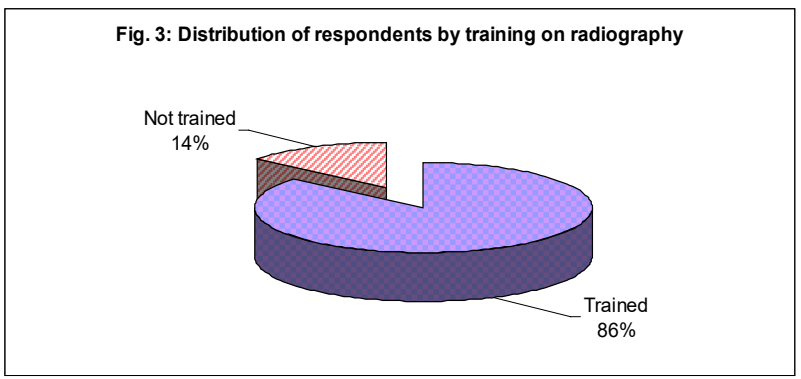

This diagram shows that $69(86.2 \%)$ respondents have training on radiography and $11(13.8 \%)$ respondents do not have any training on radiography.

Table 4: Distribution of Respondents by awareness about harmful effects of radiation

\begin{tabular}{|l|l|l|}
\hline $\begin{array}{l}\text { Awareness about } \\
\text { harmful effects of } \\
\text { radiation }\end{array}$ & $\begin{array}{l}\# \quad \text { Respondent } \\
(\mathbf{n = 8 0})\end{array}$ & $\mathbf{\%}$ \\
\hline Blood cancer & 71 & 88.8 \\
\hline Skin cancer & 56 & 70.0 \\
\hline Eye cataract & 42 & 52.5 \\
\hline Alopecia & 31 & 38.8 \\
\hline Anemia & 42 & 52.5 \\
\hline Diarrhoea & 10 & 12.5 \\
\hline Weakness & 36 & 45.0 \\
\hline
\end{tabular}

* Multiple responses
This table shows distribution of the respondents by awareness about harmful effects of radiation. It was a multiple response question.71(88.8\%) respondents said x-ray radiation could cause blood cancer, $56(70 \%)$ respondents said about skin cancer, $42(52.5 \%)$ said about cataract, 31(38.8\%) said about alopecia, 42 $(52.5 \%)$ said about anaemia, $10(12.5 \%)$ said about diarrhoea and 36(45\%) said about weakness.

Table 5: Distribution of Respondents by awareness regarding harmful effects of X-ray on reproductive health

\begin{tabular}{|c|c|c|}
\hline $\begin{array}{c}\text { Awareness about harmful effects of } \\
\text { radiation on reproductive health }\end{array}$ & $\begin{array}{c}\text { Respondent } \\
(\mathbf{n}=\mathbf{7 9})\end{array}$ & $\mathbf{\%}$ \\
\hline Infertility & 59 & 74.7 \\
\hline Abortion & 39 & 49.4 \\
\hline Stillbirth & 30 & 38.0 \\
\hline Congenital malformation & 50 & 63.3 \\
\hline Physical/Mental retardation & 36 & 45.6 \\
\hline Childhood cancer & 26 & 32.9 \\
\hline
\end{tabular}

* Multiple responses

This table shows distribution of the respondents by awareness about harmful effects of radiation on reproductive health. Out of 79 respondents $59(74.7 \%)$ knew about infertility, 39(49.4\%)about abortion, 30(3 8\%) about stillbirth, 50(63.3\%) about congenital malformation, 36(45.6\%) about physical /mental retardation, 26(32.9\%) about childhood cancer. Maximum number of respondents (74.7\%) was aware about infertility.

Table 6: Distribution of the respondents by the knowledge of using personal protective devices/ equipments

\begin{tabular}{|c|c|c|}
\hline $\begin{array}{c}\text { Knowledge about protective } \\
\text { devices }\end{array}$ & Number & $\mathbf{\%}$ \\
\hline Yes & 79 & 98.8 \\
\hline No & 1 & 1.2 \\
\hline Total & 80 & 100.0 \\
\hline
\end{tabular}

This table shows the knowledge of the respondents about using of personal protective devices, where $79(98.8 \%)$ were aware about using PPD; only one was not aware.

Table 7: Awareness of the respondents about the methods of personal protective equipments

\begin{tabular}{|c|c|c|}
\hline PPE & \# Respondent $\mathbf{( n = 7 9 )}$ & $\mathbf{\%}$ \\
\hline Lead apron & 77 & 97.5 \\
\hline Lead goggles & 33 & 41.8 \\
\hline Lead gloves & 41 & 51.9 \\
\hline Protection stand & 39 & 49.4 \\
\hline
\end{tabular}

* Multiple responses 
This table shows that out of 79 respondents $77(97.5 \%)$ were aware about using lead apron, 33(41.8\%) about lead goggles, 41(51.9\%)about lead gloves and $39(49.4 \%)$ about protection stand.

Table 8: Distribution of the respondents by using personal protective devices/equipments.

\section{Fig. 4: Distribution of respondents by using} personal protective equipments (PPE)

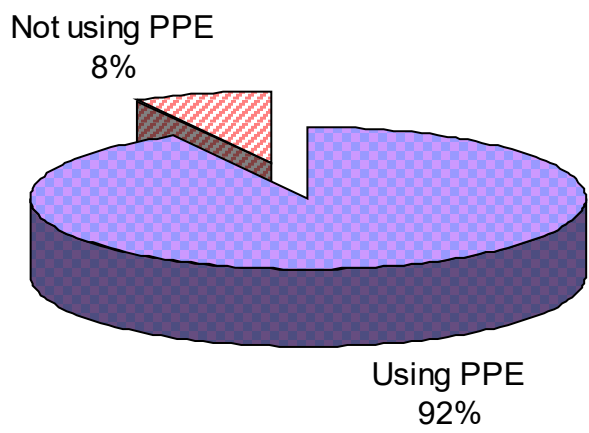

This diagram shows that most of the workers (74workers; 92.5\%) use personal protective devices, while only $6(7.5 \%)$ do not.

Table 9: Reasons for not using personal protective devices/ Equipments

\begin{tabular}{|l|l|l|}
\hline Reasons for not using PPE & \# Respondent $(\mathbf{n}=\mathbf{6})$ & $\mathbf{\%}$ \\
\hline Not easily available & 4 & 66.7 \\
\hline Do not feel necessary & 2 & 33.3 \\
\hline
\end{tabular}

This table shows the reason for not using PPD/PPE. Out of 6 respondents $4(66.7 \%)$ told that it is not easily available, when $2(33.3 \%)$ told that it is not necessary.

Table 10: Distribution of the respondents by the knowledge about Radiation monitoring

\begin{tabular}{|l|c|c|}
\hline Knowledge about radiation monitoring & Number & $\mathbf{\%}$ \\
\hline Yes & 78 & 97.5 \\
\hline No & 2 & 2.5 \\
\hline Method of radiation monitoring $(\mathrm{n}=78)$ & Number & $\%$ \\
\hline Film badge & 44 & 56.4 \\
\hline Thermo luminescence dosimeter & 49 & 62.8 \\
\hline
\end{tabular}

* Multiple responses

This table shows the distribution of the respondents by the knowledge about radiation monitoring. 78 $(97.5 \%)$ respondents were aware about radiation monitoring, while $2(2.5 \%)$ were not. Out of 78 , 44(56.4\%) knew about film badge and 49(62.8\%) knew about thermo luminescence dosimeter.
Table 11: Distribution of the respondents by using monitoring Devices.

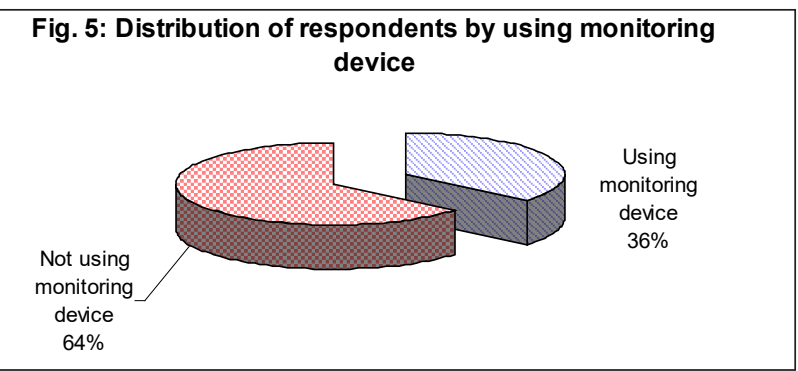

This diagram shows the distribution of the respondents by using monitoring devices. Only $29(36.2 \%)$ use monitoring devices, while 51(63.8\%) do not. Out of 29 only 10 respondents use it regularly and $19(65.5 \%)$ use sometimes. Out of 51 who do not use monitoring devices, 50(98\%) said it is not easily available and only one person said it is not necessary.

Discussion: The study revealed that the mean age of the respondents was 36.67 years. Male respondents were $93.8 \%$ whereas females were only $6.2 \%$. Working as medical technologists is a new concept for women, so only 5 female radiographic workers were found during the study period that matched the criteria. Among 80 respondents only 3 were Hindu. The rest were Muslims.

Among all the respondents 45\% were Diploma holders in radiography. $10 \%$ were graduate, $5 \%$ were Masters degree holder and the rest were HSC and SSC passed. No one was found below SSC. In the study by Mitra $\mathrm{SK}^{6}$ among 38 respondents $52 \%$ were HSC and 13\% were SSC passed and 9\% were graduate. No one was Diploma or Masters degree holder.

Out of 80 respondents, $69(86.2 \%)$ respondents had training on radiography and $11(13.8 \%)$ respondents did not have any training on radiography. While in the study by Mitra SK $^{6} 55.26 \%$ trained technicians were found. The reason for this may be, as day passed the recruitment of more educated and trained personnel in this field are occurring.

During the data collection it was found that most of the workers work in more than one place. Those who were employed in Government hospitals have part- time jobs in private clinics. Among workers of private clinics most were working in two x-ray installations. For this specific reason overexposure of radiation of the workers may occur.

Out of 80 radiographic workers $47.5 \%$ were working for $11-20$ years, $22.5 \%$ were working for more than 
20 years. The rest were working for less than 10 years. The mean length of service of all workers was 15.38 years .The length of service was less among females. None of them was found to work for more than 10 years.

Most of the radiographic workers (about 50\%) work for 7-8 hours a day on average, $23.8 \%$ work for more than 8 hours. The rest work for less than 7 hours on average.

All the respondents were aware about adverse effects of radiation. More than $88 \%$ knew that $\mathrm{x}$-ray radiation might cause blood cancer, $70 \%$ were aware about skin cancer. $45 \%$ said vague terms like weakness.

Almost all the workers knew about adverse effects of radiation on reproductive health. Only one person was unaware about it. When asked about the reproductive disorders maximum respondents $(74.7 \%)$ said radiation might cause infertility. More than $63 \%$ were aware that congenital malformation of the next generation might occur due to radiation exposure.

$98.8 \%$ of the respondents knew that personal protective equipments must be used to avoid unwanted exposures. 97.5\% said that lead apron must be used during working hour. About 92.5\% said that they use some kind of protective devices. Most of them meant that it is the protection stand or lead shielded glass, which protect them from radiation. Lead apron was found available in few private diagnostic centers. Where available, the workers were quite reluctant to use those. The reason they told about not using, that it is difficult to work in the hot weather with lead apron on. $97.5 \%$ of the respondents had the knowledge about radiation monitoring. $56 \%$ of them knew about film badge and $63 \%$ about thermo luminescence dosimeter. Although the radiographic workers had good knowledge about radiation monitoring, only $36 \%$ used monitoring device, as because it was not easily available to all the workers. In a study done by D'souza AI, it was found that $83.7 \%$ of the radiographic workers were aware of the occupational health safety measures ${ }^{7}$.

Despite the fact that Bangladesh Government has set the rules (Nuclear safety and radiation control act1993; Nuclear safety and radiation control rules-1997) for radiation monitoring for the radiographic workers, only few follow them. Due to negligence and lack of knowledge of the management radiation monitoring is not done properly .So the maximum permissible dose for a person cannot be identified.

Conclusion: In relation to the occupational health hazards, this study was undertaken on radiographic workers in different X-ray installations in Dhaka city to observe the levels of awareness and use of PPE. Data were collected by direct interviewing of the respondents by using structured questionnaires. With the findings it was noted that, the duration of average working hour i.e. hour of exposure was 7-8 hours for most of the workers. The workers were quite aware about the potential health problems and reproductive hazards due to radiation exposure but as they were not provided with sufficient protective equipments and monitoring devices, their uses at workplace were lower than expectation. Even though the workers were aware of the radiation safety, it would be better to update them regularly about the radiation safety. There is also scope for radiation workers to have introductory seminars. They also need continuous education and update on radiation safety. 


\section{References:}

1. Raffle PAB, Lee WR, Mccallum RI, Murray R, editors. Hunter's diseases of occupation. $6^{\text {th }}$ ed. London: Hodder and Stoughton; 1987. P. 577-88.

2. Ratcliffe JM. Altered fertility. In: Review of occupational hazards to reproductive health. Geneva, Switzerland: World Health Organization.

3. Strobino BR, Kline J, Stein Z. Chemical and physical exposures of parents: effects on human reproduction and offspring. Early human Development 1978; 1: 371-99.

4. United Nations Scientific Committee on the effects of Atomic Radiation. Ionizing Radiation Sources and
Biological Effects. Report to the General Assembly. New York: UNSCEAR, 1986. $5^{\text {th }}$ ed.

5. Brent RL.The effect of embryonic and fetal exposure to $\mathrm{x}$-ray, microwaves and ultrasound. Clinical Perinatology 1986; 13:615-22.

6. Mitra SK. A study on assessment of radiation exposure in and around the xray installations in some selected x-ray clinics (Dissertation). NIPSOM; Dhaka: 1993.

7. D'souza AI, D'cunha S, Suresh S. A study on the awareness on occupational health safety among health care professionals in radiology department in a selected hospital. RGUHS J Med Sciences 2013;3(2). 